\title{
Depression and suicide risk among Nursing professionals: an integrative review
}

\author{
Depressão e risco de suicídio entre profissionais de Enfermagem: revisão integrativa \\ Depresión y riesgo de suicidio entre profesionales de Enfermería: revisión integradora
}

Darlan dos Santos Damásio Silva ${ }^{1}$, Natália Vieira da Silva Tavares ${ }^{2}$, Alícia Regina Gomes Alexandre ${ }^{2}$, Daniel Antunes Freitas $^{3}$, Mércia Zeviani Brêda ${ }^{4}$, Maria Cícera dos Santos de Albuquerque ${ }^{4}$, Valfrido Leão de Melo Neto $^{3}$

${ }^{1}$ Universidade Federal de Alagoas, Programa de Pós-Graduação em Psicologia, Maceió, AL, Brazil.

${ }^{2}$ Universidade Federal de Alagoas, Escola de Enfermagem e Farmácia, Curso de Graduação em Enfermagem, Maceió, AL, Brazil.

${ }^{3}$ Universidade Federal de Alagoas, Faculdade de Medicina, Maceió, AL, Brazil.

${ }^{4}$ Universidade Federal de Alagoas, Escola de Enfermagem e Farmácia, Programa de PósGraduação em Enfermagem, Maceió, AL, Brazil.

\begin{abstract}
Objective: Discussing the factors associated with major depression and suicide risk among nursing professionals. Method: An integrative review in PubMed/MEDLINE, LILACS, SciELO and BDENF databases, between 2003 and 2015. Results: 20 published articles were selected, mostly from between 2012 and 2014, with significant production in Brazil. Nursing professionals are vulnerable to depression when young, married, performing night work and having several jobs, and when they have a high level of education, low family income, work overload, high stress, insufficient autonomy and a sense of professional insecurity and conflict in the family and work relationship. Suicide risk was correlated with the presence of symptoms of depression, high levels of emotional exhaustion, depersonalization and low personal accomplishment; characteristics of Burnout Syndrome. Conclusion: Suicide risk among nursing professionals is associated with symptoms of depression and correlated with Burnout Syndrome, which can affect work performance.
\end{abstract}

DESCRIPTORS

Nursing; Stress, Psychological; Depression; Suicide; Review. 


\section{INTRODUCTION}

Depression and suicide are complex phenomena that cause intense suffering in the lives of the people affected, their families, friends and community. These two phenomena coexist and influence one another ${ }^{(1)}$, and both are considered significant public health problems ${ }^{(2)}$.

The World Health Organization $(\mathrm{WHO})^{(2)}$ estimates that depression accounts for $4.3 \%$ of the global burden of disease and is among the largest causes of disability in the world, particularly for women ${ }^{(3)}$. It also notes that suicide is a universal phenomenon, being the main cause of death among adolescents $15-19$ years. In 2012 alone there were 804,000 suicides worldwide, representing a rate of 11.4 per 100,000 (15.0 for men and 8.0 for women $)^{(2)}$. Both depression and suicide result from the interaction of biological, genetic, psychological, sociological, cultural and environmental factors, while being an important indicator of people's quality of life $\mathrm{e}^{(4)}$.

Depression is characterized by a prolongation of depression symptoms and mood swings ${ }^{(5-6)}$. The person affected by this disorder has the ability to see the world as an altered reality. Brazil has one of the highest rates of depression; $18.4 \%$ of the population has had at least one episode of depression during their lifetime, behind only France (21.0\%) and the US $(19.2 \%)^{(7)}$.

Brazil also ranked as the fourth country in Latin America to present the highest growth in the number of suicides between 2000 and 2012, with the overall rate of 4.3 per 100,000 inhabitants, but some of its states have significantly higher rates $^{(4)}$. There was an increase in suicide rates among women of $17.8 \%$ in 12 years $^{(2)}$.

In the world, the number of suicides is higher than deaths from global conflicts every year, with an increase of $60 \%$ in their rates over the last 50 years $^{(8)}$. In acknowledging the relationship between suicide and mental illness, most individuals who ended their lives in this manner had depression ${ }^{(9)}$.

WHO defines suicide as the act of killing oneself intentionally. For suicidal behavior, a variety of behaviors are considered such as suicidal thoughts, regarded as suicidal ideation, planned suicide, attempted suicide and committing suicide itself. Also, the presence of social, psychological, cultural, relational, individual factors are considered as risks for suicide that can lead a person to suicidal behavior ${ }^{(2)}$.

Understanding depression and risk for suicide, as well as the factors involved, is extremely important for studies related to the health of workers ${ }^{(9)}$. It is noteworthy that the prevalence of depression symptoms and suicide, which corresponds to the process and that the causes of death are caused by the victims themselves, is high among health professionals ${ }^{(1)}$. It should also be noted that the prevalence is influenced by environmental stress and work process, significantly interfering in the working lives of these professionals with an impact on their quality of life $\mathrm{e}^{(1)}$.
Slowness in activities, disinterest, reduced energy, apathy, difficulty concentrating, recurrent negative thoughts, loss of capacity in planning and altering the perception of truth are evidence of human suffering that signal depression and possible suicide risk ${ }^{(6,9)}$.

Among health workers, nurses are the group most prone to mental health problems, with depression and suicide risk among them, because they deal with human suffering, pain, joy, sadness and they need to offer help to those who need their care ${ }^{(1,9)}$. Other commonly found factors such as the difficult working conditions and lack of professional recognition can also be highlighted ${ }^{(5)}$.

Depression is one of the three most occurring conditions mentioned by nursing staff(6), therefore, those responsible for health services should identify this problem early on, promote health at work, avoid sad and fatal outcomes, as well as the decrease or loss of care quality $^{(1,5,10)}$.

The high rates of depression and risk for suicide are in contrast with the work performed by nursing professionals who are generally expected to provide care ${ }^{(5)}$, but also on the other hand, may need to be cared for.

So the question that guides this study is: What factors contribute to depression and suicide risk among nursing professionals? With the objective to discuss the factors associated with depression and risk of suicide among nursing professionals.

\section{METHOD}

This is an integrative review of the scientific literature $^{(11)}$, which brought together research findings obtained from articles of online databases, developed in five stages: formulation of the problem, data collection, data evaluation, data analysis and interpretation, and presentation of results ${ }^{(12)}$.

The integrative review analyzes research that provides information for decision making and improvement of clinical practice, and also makes it possible to synthesize knowledge on a given subject as well as point out possible gaps in the studied literature ${ }^{(11)}$.

For the search of articles, the databases used were: Latin American and Caribbean Health Sciences (LILACS), the Nursing Database (BDENF - Base de Dados de Enfermagem), National Library of Medicine, USA (PubMed), Medical Literature Analysis and Retrieval System on-line (MEDLINE) and Scientific Electronic Library Online (SciELO), a broad online index of both national and international journals in health platforms, representing the majority of those articles which have an important impact in scientific literature.

Different search strategies were defined by using MeSH(Medical Subject Headings) and DeCS (Descriptors of Health Sciences) descriptors of the terms "nursing", "suicide" and"depression"in English and Portuguese, with the combination of the Boolean term "AND", adapted to each of the databases and in three 
stages: initially, only the descriptors "nurses" AND "suicide" were used; followed by "Nursing" AND "depression" descriptors; and finally, "Nursing" AND "suicide" AND "depression". For Figure 1, the English terms were used as a reference to facilitate the search in international databases.

Articles available electronically from January 2003 to August 2015 were included, as it is an updated and at the same time comprehensive time frame on the subject.

The selection by reading the titles was carried out first, then later by reading the abstracts and full articles, as shown in Figure 1.32 articles were chosen, of these, 20 were related to the objective of the study, by answering the guiding question and meeting the inclusion criteria. The five publications repeated in more than one database were only analyzed once. The literature search was conducted in Portuguese, Spanish and English.

The studies selected were then organized by a compilation of reviews/annotations, allowing for better organization of notes, and thereby establishing a very useful tool for later reference. Next, the articles were reread in full, in order to perform an interpretative analysis based on the guiding question and stated objectives. To facilitate data analysis, a summary chart (Chart 1) containing the variables was used. Topics of interest were: article title, year and country of publication, the type of study design, the sample containing the number of nurses surveyed or the number of articles, and the outcomes.

\section{RESULTS}

The publication countries of the studies read in full (excluding the repeated ones) that comprised the sample ( $\mathrm{n}=20)$ were: Brazil, with eleven studies; Spain and Taiwan, two studies each; Australia, Canada, South Korea, the United States and Turkey, with one study each. Studies published in Brazil were all published in Portuguese; of these five, were also in English and two in Spanish. For those published in Spain, one was only in Spanish and one in English and Spanish, while those from Australia, Canada, South Korea, the United States and Turkey were only in English.

From the selected studies, sample characterization according to the year of publication with the corresponding quantitative studies is presented in Table 1.

Table 1 - Sample distribution by year of publication - Maceió, AL, Brazil, 2015.

\begin{tabular}{cc}
\hline Year of publication & Number of studies \\
\hline 2004 & 1 \\
2007 & 1 \\
2008 & 2 \\
2010 & 2 \\
2011 & 2 \\
2012 & 3 \\
2013 & 4 \\
2014 & 3 \\
2015 & 2 \\
\hline Total & $\mathbf{2 0}$ \\
\hline
\end{tabular}
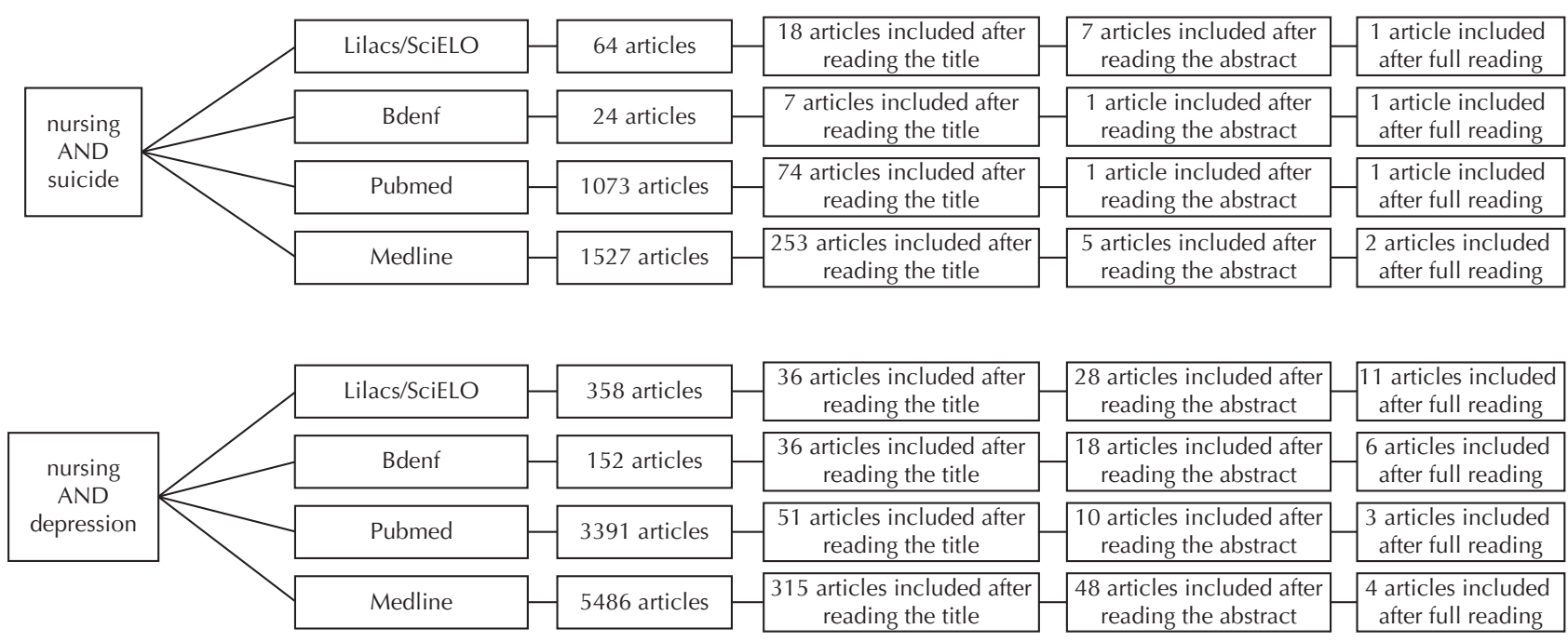

11 articles included after full reading reading the abstract

6 articles included after full reading
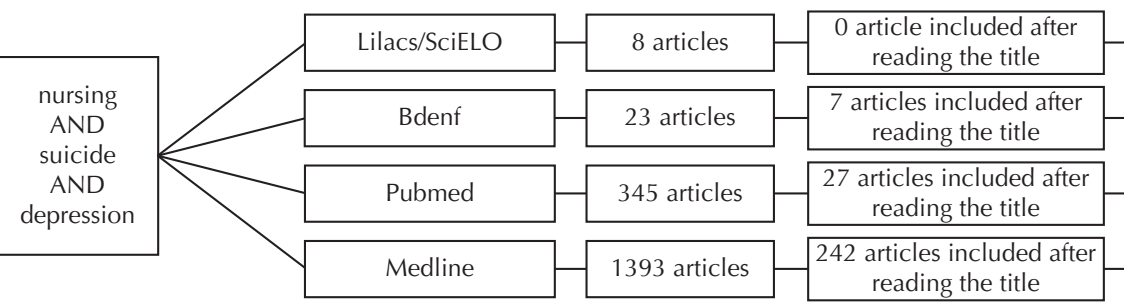

\begin{tabular}{|c|}
\hline $\begin{array}{c}0 \text { article included after } \\
\text { reading the abstract }\end{array}$ \\
\hline $\begin{array}{c}1 \text { article included after } \\
\text { reading the abstract }\end{array}$ \\
\hline $\begin{array}{c}0 \text { article included after } \\
\text { reading the abstract }\end{array}$ \\
\hline $\begin{array}{c}6 \text { articles included after } \\
\text { reading the abstract }\end{array}$ \\
\hline
\end{tabular}

\begin{tabular}{|c|}
\hline $\begin{array}{c}0 \text { article included } \\
\text { after full reading }\end{array}$ \\
\hline $\begin{array}{c}1 \text { article included } \\
\text { after full reading }\end{array}$ \\
\hline $\begin{array}{c}\text { article included } \\
\text { after full reading }\end{array}$ \\
\hline $\begin{array}{c}2 \text { articles included } \\
\text { after full reading }\end{array}$ \\
\hline
\end{tabular}

Figure 1 - Selection of articles by groups of descriptors in the database. 
Table 1 shows the studies that comprise this integrative review in ascending order of year, country, title, and an outline of study type, sample and outcomes. As a result, we found: nine cross-sectional studies; seven quantitative studies; two literature revisions; one critical review; one qualitative study.

Chart 1 - Summary of studies and their outcomes - Maceió, AL, Brazil, 2015.

\begin{tabular}{|c|c|c|c|c|}
\hline Year & Country & Title & Study design/Sample & Factors \\
\hline 2004 & Brazil & $\begin{array}{l}\text { Stress and psychosomatic repercussions } \\
\text { in nursing workers from a university } \\
\text { hospital }^{(13)} \text {. }\end{array}$ & $\begin{array}{l}\text { Quantitative study, } 300 \\
\text { nursing professionals. }\end{array}$ & $\begin{array}{l}\text { Conflicting relations in personal and family } \\
\text { responsibilities; Overload; difficulty with } \\
\text { suffering; death; lack of autonomy, and } \\
\text { recognition; depression. }\end{array}$ \\
\hline 2007 & Brazil & $\begin{array}{l}\text { Aspects associated to work-related } \\
\text { depression on nursing staff }{ }^{(14)} \text {. }\end{array}$ & $\begin{array}{l}\text { Literature review, } 10 \\
\text { articles. }\end{array}$ & $\begin{array}{l}\text { Graveyard shifts; interpersonal relationship; } \\
\text { service overload; lack of autonomy; insecurity; } \\
\text { conflict of interest and family income. }\end{array}$ \\
\hline 2008 & Brazil & $\begin{array}{l}\text { Cognitive and emotional effects } \\
\text { of occupational stress in nursing } \\
\text { professionals } s^{(15)} \text {. }\end{array}$ & $\begin{array}{l}\text { Quantitative study, } 66 \\
\text { nursing professionals. }\end{array}$ & Conditions and work organization. \\
\hline 2008 & Turkey & $\begin{array}{l}\text { Effects of Perceived Job Insecurity } \\
\text { on Perceived Anxiety and Depression in } \\
\text { Nurses }{ }^{(16)} \text {. }\end{array}$ & $\begin{array}{l}\text { Cross-sectional study, } \\
462 \text { nurses. }\end{array}$ & Life events, job insecurity. \\
\hline 2010 & Spain & $\begin{array}{l}\text { Síndrome de Burnout y riesgo suicida en } \\
\text { enfermeras de atención primaria }{ }^{(17)} \text {. }\end{array}$ & $\begin{array}{l}\text { Cross-sectional } \\
\text { study, } 146 \text { nursing } \\
\text { professionals. }\end{array}$ & $\begin{array}{l}\text { Burnout Syndrome, risk of suicide, } \\
\text { depersonalization, low personal } \\
\text { accomplishment. }\end{array}$ \\
\hline 2010 & Brazil & $\begin{array}{l}\text { Evaluation of Quality of Life and } \\
\text { Depression in Nursing Technicians and } \\
\text { Nursing Assistants }{ }^{(5)} \text {. }\end{array}$ & $\begin{array}{l}\text { Cross-sectional } \\
\text { study, } 266 \text { nursing } \\
\text { professionals. }\end{array}$ & Health problems and overnight shifts. \\
\hline 2011 & Brazil & $\begin{array}{l}\text { Anxiety and Depression among Nursing } \\
\text { Professionals who work in Surgical Units }{ }^{(9)} \text {. }\end{array}$ & $\begin{array}{l}\text { Cross-sectional } \\
\text { study, } 211 \text { nursing } \\
\text { professionals. }\end{array}$ & $\begin{array}{l}\text { Higher educational level, young adult, female, } \\
\text { multiple jobs. }\end{array}$ \\
\hline 2011 & Brazil & $\begin{array}{l}\text { Depression prevalence in Intensive Care } \\
\text { Unit nursing workers: a study at hospitals } \\
\text { in a northwestern city of São Paulo State }{ }^{(10)} \text {. }\end{array}$ & $\begin{array}{l}\text { Cross-sectional } \\
\text { study, } 67 \text { nursing } \\
\text { professionals. }\end{array}$ & $\begin{array}{l}\text { Graveyard/overnight shifts, double shifts and } \\
\text { marital status. }\end{array}$ \\
\hline 2012 & Brazil & $\begin{array}{l}\text { Depressive symptoms and suicidal ideation } \\
\text { in nurses and physicians care hospital }{ }^{(1)} \text {. }\end{array}$ & $\begin{array}{l}\text { Quantitative study, } 100 \\
\text { doctors and nurses. }\end{array}$ & $\begin{array}{l}\text { Work climate, ambiguous roles and the lack of } \\
\text { clarity in relation to the tasks and expectations. }\end{array}$ \\
\hline 2012 & Taiwan & $\begin{array}{l}\text { Stress, depression, and intention to leave } \\
\text { among nurses in different medical units: } \\
\text { Implications for healthcare management/ } \\
\text { nursing practice }{ }^{(18)} \text {. }\end{array}$ & $\begin{array}{l}\text { Cross-sectional study, } \\
314 \text { nurses. }\end{array}$ & Marital status and complexity of care. \\
\hline 2012 & USA & $\begin{array}{l}\text { Symptoms of Posttraumatic Stress Disorder } \\
\text { Among Pediatric Acute Care Nurses }{ }^{(19)} \text {. }\end{array}$ & $\begin{array}{l}\text { Quantitative study, } 173 \\
\text { nurses. }\end{array}$ & $\begin{array}{l}\text { Higher rates of nightmares, severe anxiety, } \\
\text { shortness of breath, severe pain, anxiety, } \\
\text { depression and Burnout Syndrome. }\end{array}$ \\
\hline 2013 & $\begin{array}{l}\text { South } \\
\text { Korea }\end{array}$ & $\begin{array}{l}\text { Perceived Stress and self-esteem Mediate } \\
\text { the Effects of Work-related Stress on } \\
\text { Depression } \\
\text { (20). }\end{array}$ & $\begin{array}{l}\text { Quantitative study, } 284 \\
\text { nurses. }\end{array}$ & High levels of stress, decreased self-esteem. \\
\hline 2013 & Brazil & $\begin{array}{l}\text { Illness and the use of psychoactive drugs } \\
\text { among nursing workers at intensive care } \\
\text { units }^{(6)} \text {. }\end{array}$ & $\begin{array}{l}\text { Quantitative study, } 49 \\
\text { nursing professionals. }\end{array}$ & $\begin{array}{l}\text { Lack of recognition, excessive workload and } \\
\text { graveyard shifts. }\end{array}$ \\
\hline 2013 & Brazil & $\begin{array}{l}\text { Depression, anxiety and social support in } \\
\text { nursing professionals }{ }^{(21)} \text {. }\end{array}$ & $\begin{array}{l}\text { Quantitative study, } 400 \\
\text { nursing professionals. }\end{array}$ & Limitations and every day challenges. \\
\hline 2013 & Brazil & $\begin{array}{l}\text { Mental illness of workers in intensive care } \\
\text { units }^{(22)} \text {. }\end{array}$ & $\begin{array}{l}\text { Qualitative study, eight } \\
\text { nursing professionals. }\end{array}$ & $\begin{array}{l}\text { Lack of recognition and support at work, } \\
\text { overload, graveyard shift, interpersonal } \\
\text { relationship at work, clash of ethical values, lack } \\
\text { of autonomy and difficulty in dealing with death. }\end{array}$ \\
\hline 2014 & Taiwan & $\begin{array}{l}\text { The Relationships Among Work Stress, } \\
\text { Resourcefulness, and Depression Level in } \\
\text { Psychiatric Nurses }{ }^{(23)} \text {. }\end{array}$ & $\begin{array}{l}\text { Cross-sectional study, } \\
154 \text { psychiatric nurses. }\end{array}$ & $\begin{array}{l}\text { Marital status, complexity of care, insecurity in } \\
\text { developing activities and high levels of stress. }\end{array}$ \\
\hline 2014 & Canada & $\begin{array}{l}\text { Critical Review on Suicide Among } \\
\text { Nurses }^{(24)} \text {. }\end{array}$ & $\begin{array}{l}\text { Critical review, nine } \\
\text { articles. }\end{array}$ & High levels of stress and anxiety. \\
\hline 2014 & Spain & $\begin{array}{l}\text { Marco actual del suicidio e ideas suicidas } \\
\text { en personal sanitario }{ }^{(25)} \text {. }\end{array}$ & $\begin{array}{l}\text { Literature review, } 20 \\
\text { articles. }\end{array}$ & $\begin{array}{l}\text { Work problems, marital status, family life, } \\
\text { gender, age, alcohol and other drugs, stress. }\end{array}$ \\
\hline 2015 & Australia & $\begin{array}{l}\text { The mental health of nurses in acute } \\
\text { teaching hospital settings: a cross-sectional } \\
\text { survey }^{(26)} \text {. }\end{array}$ & $\begin{array}{l}\text { Cross-sectional study, } \\
1,215 \text { nurses. }\end{array}$ & Graveyard shift and alcohol consumption. \\
\hline 2015 & Brazil & $\begin{array}{l}\text { Symptoms of depression and intervening } \\
\text { factors among nurses of emergency } \\
\text { hospital services }^{(27)} \text {. }\end{array}$ & $\begin{array}{l}\text { Cross-sectional study, } \\
23 \text { nurses. }\end{array}$ & $\begin{array}{l}\text { Interpersonal conflict in the workplace, low pay, } \\
\text { workload and work environment. }\end{array}$ \\
\hline
\end{tabular}




\section{DISCUSSION}

By identifying the studies that referred to the factors which contribute to the onset of depression and risk of suicide among nursing professionals, it became evident in this integrative review that most $(10-50 \%)$ were published between the years 2012 and 2014, and the country with the largest amount of publication was Brazil with 11 (55\%), followed by Spain with two (10\%), Taiwan with two (10\%), and Australia, Canada, South Korea, the United States and Turkey with one (5\%) each. This suggests that researchers in Brazil have begun to show interest in understanding the implications of these two phenomena in the work context of nursing professionals.

Nursing is a profession that is susceptible to mental disorders, because nurses deal with life, pain and death of people under their care on a daily basis, and also the family's expectations ${ }^{(1,5,10,13,16,18,21,28)}$. Depression is one of the illnesses that most affects these professionals, causing damage to their work capacity and personal lives ${ }^{(1,5-6,10,13-14)}$. Because the state of depression is a predictor for increased risk of suicide ${ }^{(17,22)}$, nursing professionals exhibit higher risk for suicide ${ }^{(5)}$.

Table 2 summarizes the content in alphabetical order that has emerged from the analysis of the data found about the factors that contribute to Depression and influence Suicide Risk.

Table 2 - Content that has arisen.

\begin{tabular}{cc}
\hline Depression & Suicide Risk \\
\hline Work environment & Depression \\
Family conflicts & Burnout Syndrome \\
Interpersonal conflict in the workplace & Low personal fulfilment \\
Marital status & \\
Stress & \\
Lack of professional autonomy & \\
Insecurity in developing activities & \\
Young adults & \\
Higher educational level & \\
Graveyard/Night shifts & \\
Family Income & \\
Work overload & \\
\hline
\end{tabular}

\section{FACTORS CONTRIBUTING TO DEPRESSION}

\section{WORK ENVIRONMENT}

The daily exposure of nurses to external physical and mental stimuli related to the complexity of the work, the absence of ideal conditions taking precautions when dealing with people with serious illnesses and the risk of death leads them to develop depression more easily ${ }^{(5,17,20,23)}$. Unhealthy working environments with poor conditions, coupled with the presence of internal conflicts and the pressure of the institution and patients' families maximize these professionals' risk for depression and suicide $\mathrm{e}^{(5,10,17,25,27)}$.

\section{FAMILY CONFLICTS}

Factors involving relationships were also identified as influential for symptoms of depression, particularly those associated with imbalances in the family lives of nursing professionals ${ }^{(1)}$. It has also been confirmed that family loss, absence of family and marital support increase the odds for suicide risk ${ }^{(2,10)}$

It is worth mentioning that the operating mode of nursing professionals diminishes family contact, and the lack of this contact can lead to depression ${ }^{(10)}$. Tiredness and overwork compromise the dialogue of these professionals within the family ${ }^{(29)}$, as well as conflicts between having to meet the demands of nursing and reconciling with family responsibilities contribute to relationship wear ${ }^{(13)}$, along with having night and weekend shifts often taking the place of quality time spent with family ${ }^{(10)}$.

A study revealed that nursing professionals exhibit higher depression than medical professionals/doctors, and that a person with depression affects their social life and family ${ }^{(6)}$.

Although there are still no studies linking family conflicts in nursing and risk for suicide, a study ${ }^{(30)}$ confirmed that family and marital conflicts are the third cause that appears on psychological autopsies of elderly who committed suicide.

\section{INTERPERSONAL CONFLICTS IN THE WORKPLACE}

Interpersonal conflicts in the workplace are common and appeared as factors that lead to depression ${ }^{(22)}$. Nurses have mentioned the precariousness of interpersonal relationships, since health work is influenced and controlled by the relationships between people, which requires cohesion and collaborative participation ${ }^{(27,29)}$. Due to the relational aspects of nursing work, they can cause irritability, generate conflicts and interpersonal difficulties with the other team members, but also with managers, users and extend to their families ${ }^{(15,31)}$.

One of the measures to improve interpersonal relationships in the nursing work environment is access to relational technologies ${ }^{(29)}$. These can be promoted through dialogue, listening, bonding and acceptance, with the view that they raise the understanding of suffering, valuing experience and attention to the needs of the different people involved in the work process ${ }^{(32)}$.

\section{MARITAL STATUS}

Marital status and the position held by nursing professionals appeared as significant for the development of depression and stress ${ }^{(18)}$. This profession is made up mostly of women, and married women who deal with the working world in their daily lives, meet the demands of their children, their partner and their house, which increases the development of a stress framework that can culminate with depression ${ }^{(1,18)}$. Nurses working in medical clinics, especially those who are married, are susceptible to developing depression and quitting their job ${ }^{(18)}$, on top of damaging marital relations or delaying marriage.

\section{StRess}

One study ${ }^{(23)}$ revealed stress as a predictor of depression. Higher level of stress is associated with lower skill and safety to perform the work in the health professions. The highly complex activities and demand of nursing professionals also produces high levels of stress and consequently 
correlate with high levels of depression, for example nurses who work in psychiatric nursing, intensive care units and operating rooms ${ }^{(6,9,23)}$.

Work conditions have transformed the stress into something familiar and often normal, with implications on the health of nursing professionals, highlighting the need for the use of internal and external strategies to minimize stress through coping strategies to control, tolerate and reduce the effects of adverse stimuli ${ }^{(20,29,31,33-34)}$.

\section{LACK OF PROFESSIONAL AUTONOMY}

Another contributing factor to mental illness concerns the lack of professional nursing autonomy ${ }^{(5)}$. The necessity to abide by the standards established by the hospital makes the nurse decrease the autonomy of the nursing team, since the control and power of the sector is not within their responsibility, thus affecting their activities and causing mental illnesses ${ }^{(13)}$. A study found that nurses restrict the autonomy of their subordinates because of the role they need to perform ${ }^{(13)}$.

\section{INSECURITY IN DEVELOPING ACTIVITIES}

A study showed that depression in nurses was also associated with insecurity in developing their work activities, which are characterized by high expectation standards, especially when they are highly complex or involve the possibility of patient death ${ }^{(14,22)}$.

At times, psychological distress has contributed to coping with professional demands through the desire to escape from responsibilities with passivity and pessimism, common in depression ${ }^{(14)}$.

\section{YOUNG ADULTS}

A study ${ }^{(9)}$ showed that depression affects younger groups of nursing professionals on a larger scale than those at an older age. The vulnerability of the first group could be linked to lack of experience in dealing with everyday situations in the workplace. This led to infer that maturity (cognitive, emotional and physical) generates security in the professional for resolving problems and facing adversities.

\section{Higher eDUCATIONAL LEVEL}

Nurses with higher education levels, such as a specialization, a master's or doctoral degree, are more affected by depression ${ }^{(9)}$, even though nurses are encouraged to expand their training constantly and acquiring new titular status will enable a salary increase and professional growth. These result in more requirements for job performance and consequently the acquisition of new responsibilities, generating overload and more chance for mental illness ${ }^{(10)}$.

\section{GRAVEYARD/NIGHT SHIFTS}

Working the night shift brings damage and risk to worker's health because it is exhausting and tiring ${ }^{(10,26)}$, which can worsen when the environment has critical working conditions, such as in the Intensive Care Unit, increasing the effects on the mental health of these workers ${ }^{(10)}$.
Night shifts, specifically, represent a risk factor for developing major depression ${ }^{(1)}$. A study ${ }^{(5)}$ demonstrated that night shift workers have higher depression scores. Another study ${ }^{(6)}$ stated that the night shift had the highest quantity of nursing professionals with psychiatric illness and that the more frequent and prolonged the night work was in the life of the nursing professional, the more labor compromise would be displayed.

\section{FAMILY INCOME}

Depression can also occur more frequently in nursing professionals with low family income. The lower the pay, the higher the prevalence of depression ${ }^{(6,14)}$. The association between family income and the increase in the level of depression was also observed in nursing students ${ }^{(14)}$. In contrast, another study ${ }^{(10)}$ showed that the more the income increases, the more the number of employment relationships increases, which can be exhausting, causing impacts on the mental health of these workers. However, a study ${ }^{(9)}$ showed high depression rates in professionals who have only one job, which may be related to low-income.

\section{WORK OVERLOAD}

Work overload is considered a contributing factor to increased emotional and physical stress, which can trigger several illnesses $^{(6,10,13)}$. It also leads to mental illness and is considered a triggering factor of depression ${ }^{(1,9,27)}$. Studies $^{(6,10,19)}$ revealed that work overload produced physical and psychological wear and tear on the nursing staff in the ICU, and among the main triggering factors found were nightmares, depression, severe anxiety and panic, thereby leading to Burnout Syndrome. Another study stated that overload and low wages generate excessive work hours and physical and emotional exhaustion among nurses ${ }^{(27)}$.

Studies ${ }^{(14,22,27)}$ also point out that work overload arises from a lack of professionals, especially on holidays; coworkers who do not complete all tasks and cause excessive burden for the following shift; conflicts of scale/shifts, resulting in dissatisfaction and the intention to abandon employment; and larger amounts of hospitalized patients.

It is worth noting that the work environment, family and interpersonal conflicts in the workplace, as well as marital status, lack of professional autonomy, insecurity in developing activities, age, higher education level, night shift, family income and work overload appeared as factors with significant influence for changes in mental health causing depression disorders.

\section{FACTORS CONTRIBUTING TO SUICIDE RISK}

Studies ${ }^{(1,17,22,24-25,29-30,35-38)}$ revealed that nurses have a high risk for suicide. Records indicate that in some countries, the risk of suicide among nurses is higher than in the general population; for example, in Denmark, Australia, and New Zealand, while Norway has a higher prevalence of suicide among nurses than other health professionals ${ }^{(25)}$. Risk factors can be: depression, low self-fulfillment and Burnout Syndrome. 


\section{DEPRESSION}

The risk of suicide was positively and significantly correlated with depression ${ }^{(17,25)}$. Studies ${ }^{(1,25)}$ showed that the prevalence of depression symptoms is more pronounced among nursing professionals. Using the known diagnostic reconstruction technique (psychological autopsy), it was noted that psychiatric disorder is one of the biggest risk factors for suicide, and suicidal behavior is quite common among most groups of people with psychiatric diagnoses, and major depression disorder is most prevalent among suicide victims ${ }^{(1,30,35-36)}$.

\section{LOW PERSONAL FULFILMENT}

Studies ${ }^{(1,17)}$ revealed that there is a correlation between risk of suicide and self-fulfillment. The less nurses succeed in the exercise of their profession, the more they appear to have negative responses to themselves and their work; symptoms such as low self-esteem, irritability, decreased interest in sexual activity, lack of appetite, interpersonal relationship avoidance with colleagues, self-punitive feelings, low productivity, lack of interest in work and depression are very likely to increase the risk of suicide ${ }^{(1,17,35-36)}$. In contrast, there was a significant negative correlation between risk for suicide with high self-esteem and personal fulfillment ${ }^{(17)}$.

\section{BurnOUT SYNDROME}

Another predictor for the risk of suicide is emotional exhaustion, which is characterized by loss of energy, wear, exhaustion and fatigue; an emotional state closely related to components of depression, consistent with the principle component of Burnout implicated by suicide ${ }^{(17,25,29)}$. Among the many common symptoms of this illness, harmful acts or suicide appeared as one of the most alarming ${ }^{(22)}$. In the case of nurses, in general, only one study ${ }^{(17)}$ showed relatively low levels of Burnout and suicide risk among these professionals compared to other studies. However, it should be noted that in the same study there was a high level of emotional exhaustion, high depersonalization, and low personal fulfilment, features that may lead to Burnout Syndrome symptoms and consequently risk of suicide ${ }^{(17)}$.

Also, factors such as a lack of knowledge and motivation for career development are related to Burnout Syndrome ${ }^{(29)}$. Professionals expect recognition from those who are close to them in their daily practice, but it does not always happen, possibly leading to feelings of incompetence, failure, despair, helplessness and suicidal tendencies ${ }^{(22,25)}$.

This research revealed that the risk of suicide among nurses is associated with the presence of factors such as depression, low self-accomplishment and Burnout Syndrome. Other studies ${ }^{(37-38)}$ report that it is difficult to prevent suicide, given the complexity of discovering the imminent risk of suicidal behavior; however, they may contribute to its prevention and risk evaluation, for the identification of risk factors through the use of strategies which include: restriction on highly lethal means, use of tracking methods and identification of those at risk, suicide risk management, education of the general population, coverage by responsible media, diagnosis and effective treatments, continuing education of health teams for intervening in a multimodal and interdisciplinary manner ${ }^{(38)}$.

\section{CONCLUSION}

This integrative review showed that studies on depression and suicide risk among nursing professionals have been published mostly between the years 2012 and 2014, with significant production in Brazil.

Risk factors for depression among nursing professionals concerning work, human relationships and personal characteristics, and the risk of suicide associated with the presence of mental disorders and the professional environment have been identified. It has been found that depression of these professionals is influenced by factors such as the work environment, family and interpersonal conflicts among workers, marital status, stress, lack of professional autonomy, insecurity in developing activities, age, educational level, night shifts, family income, and work overload. This study also demonstrated that depression, Burnout Syndrome and low personal accomplishment contribute to suicide risk in this category of professionals.

Therefore, it was identified that nursing professionals who perform activities in unhealthy environments with conflicting interpersonal and/or family relationships and in the workplace, married, with high levels of stress, a lack of professional autonomy, with insecurity to develop their work activities, younger, better educated, working on night shifts, with low family income, several employment relationships and work overload are more vulnerable to developing depression. Also, there is a risk for suicide in those who already have symptoms of depression and high levels of emotional exhaustion, high depersonalization and low personal accomplishment; characteristics of Burnout Syndrome.

It is worth mentioning that all the factors directly related to depression may also be indirectly related to the risk of suicide, because depression is considered a predictor of it. All of these factors alone or combined can influence the health care services provided.

It is important to consider health and quality of life of nursing professionals given that their professional practice occurs in complex realities, with the most diverse human relationships, having to routinely deal with different requirements, being faced with factors that can produce risk for depression and suicide, and that contribute to the illness and compromise the delivery of care.

Nursing professionals must be understood not only as a health worker, but they should also be seen as a person who may suffer harm to their own health. Thus, the aim of this study was to draw attention to the seriousness of the risks involved, both in their work and in their personal lives for developing mental disorders, which is often overlooked, even by the professionals themselves. Evidence reinforces the need to identify early risk factors for depression and suicide in workers in this occupational category, as well as elements so that nurses can recognize them and evaluate them in their team.

From the analysis of the studies, it became clear that there is alack of research/studies aimed at identifying, 
diagnosing and intervening on these factors and with this specific audience in order to prevent progression to severe depression conditions, and subsequently to a high risk of suicide.
Therefore, this study may have implications for the prevention, early detection, treatment and psychosocial rehabilitation of nursing professionals, who face factors related to depression and risk for suicide in their daily work.

\section{RESUMO}

Objetivo: Discutir sobre os fatores associados à depressão maior e risco de suicídio entre profissionais de enfermagem. Método: Revisão integrativa em bases de dados PubMed/MEDLINE, LILACS, SciELOe BDENF, entre 2003 e 2015. Resultados: Selecionaram-se 20 artigos publicados, a maioria entre 2012 e 2014, com significativa produção no Brasil. Os profissionais de enfermagem são vulneráveis à depressão quando jovens, casados, realizam trabalho noturno e possuem vários empregos, e quando apresentam alto nível educacional, baixa renda familiar, sobrecarga de trabalho, estresse elevado, insuficiente autonomia e sentimento de insegurança profissional, conflitos no relacionamento familiar e no trabalho. Risco de suicídio foi correlacionado com a presença de sintomas de depressão, alto nível de exaustão emocional, despersonalização e baixa realização pessoal; características da Síndrome de Burnout. Conclusão: Risco de suicídio entre os profissionais de enfermagem está associado a sintomas depressivos e os correlacionados com a Síndrome de Burnout, prejudicando o desempenho profissional.

\section{DESCRITORES}

Enfermagem; Estresse Psicológico; Depressão; Suicídio; Revisão.

\section{RESUMEN}

Objetivo: Discutir sobre los factores asociados con la depresión mayor y el riesgo de suicidio entre profesionales de enfermería. Método: Revisión integradora en las bases de datos PubMed/MEDLINE, LILACS, SciELO y BDENF, entre el año 2003 y el 2015 . Resultados: Se seleccionaron 20 artículos publicados, la mayoría entre el 2012 y el 2014, con significativa producción en Brasil. Los profesionales de enfermería son vulnerables a la depresión cuando jóvenes, casados, realizan trabajo nocturno y tienen varios empleos, y cuando presentan alto nivel educativo, bajos ingresos familiares, sobrecarga de trabajo, estrés elevado, insuficiente autonomía y sentimiento de inseguridad profesional, conflictos en la relación familiar y laboral. El riesgo de suicidio fue correlacionado con la presencia de síntomas de depresión, alto nivel de agotamiento emocional, despersonalización y baja realización personal; características del Síndrome de Burnout. Conclusión: El riesgo de suicidio entre los profesionales de enfermería está asociado con los síntomas depresivos y los correlacionados con el Síndrome de Burnout, perjudicando el desempeño profesional.

\section{DESCRIPTORES}

Enfermería; Estrés Psicológico; Depresión; Suicidio; Revisión.

\section{REFERENCES}

1. Barbosa KKS, Vieira KFL, Alves ERP, Virgínio NA. Sintomas depressivos e ideação suicida em enfermeiros e médicos da assistência hospitalar. RevEnferm UFSM [Internet]. 2012 [citado 2014 out. 14]; 2(3):515-522. Disponível em: http://cascavel.ufsm.br/revistas/ojs-2.2.2/ index.php/reufsm/article/view/5910

2. World Health Organization. Preventing suicide: a global imperative. Geneva: WHO: 2014

3. World Health Organization. Comprehensive mental health action plan 2013-2020. Geneva: WHO; 2013.

4. Heck RM, Kantorski LP, Borges AM, Lopes CV, Santos MC, Pinho LB. Ação dos profissionais de um centro de atenção psicossocial diante de usuários com tentativa e risco de suicídio. Texto Contexto Enferm [Internet]. 2012 [citado 2014 out. 24]; 21(1):26-33. Disponível em: http://www.scielo.br/pdf/tce/v21n1/a03v21n1

5. Rios KA, Barbosa DA, Belasco AGS. Evaluation of quality of life and depression in nursing technicians and nursing assistants. Rev Latino Am Enfermagem [Internet]. 2010 [cited 2014 Oct 12];18(3):413-20. Available from: http://www.scielo.br/pdf/rlae/v18n3/17.pdf

6. Vieira TG, Beck CLC, Dissen CM, Camponogara S, Gobatto M, Coelho APF. Adoecimento e uso de medicamentos psicoativos entre trabalhadores de enfermagem de unidades de terapia intensiva. RevEnferm UFSM [Internet]. 2013 [citado 2014 out. 14];3(2):205-14. Disponível em: http://cascavel.ufsm.br/revistas/ojs-2.2.2/index.php/reufsm/article/view/7538

7. Bromet E, Andrade LH, Hwang I, Sampson NA, Alonso J, Girolamo G,et al. Cross-national epidemiology of DSM-IV major depressive episode. BMC Med [Internet]. 2011 [cited 2014 Oct 25];9:90. Available from: http://www.ncbi.nlm.nih.gov/pmc/articles/PMC3163615/

8. Organização Mundial de Saúde. Saúde pública ação para prevenção de suicídio. Genebra: OMS; 2012.

9. Schmidt DRC, Dantas RAS, Marziale MHP. Anxiety and depression among nursing professionals who work in surgical units. Rev Esc Enferm USP [Internet]. 2011 [cited 2014 Oct 12];45(2):487-93. Available from: http://www.scielo.br/pdf/reeusp/v45n2/en_v45n2a25.pdf

10. Vargas D, Dias APV. Depression prevalence in Intensive Care Unit nursing workers a study at hospitals in a northwestern city of São Paulo State. Rev Latino Am Enfermagem[Internet]. 2011 [cited 2014 Oct 12]; 19(5):1114-21. Available from: http://www.scielo.br/pdf/ rlae/v19n5/08.pdf

11. Mendes KDS, Silveira RCCP, Galvão CM. Revisão integrativa: método de pesquisa para a incorporação de evidências na saúde e na enfermagem. Texto Contexto Enferm. 2008;17(4):758-64.

12. Bezerra FN, Silva TM, Ramos VP. Occupational stress of nurses in emergency care: an integrative review of the literature. Acta Paul Enferm [Internet]. 2012 [cited 2014 Oct 20];25(n. spe 2):151-6. Available from: http://www.scielo.br/pdf/ape/v25nspe2/24.pdf 
13. Belancieri MF, Bianco MHBC. Estresse e repercussões psicossomáticas em trabalhadores da área da enfermagem de um hospital universitário. Texto Contexto Enferm. 2004;13(1):124-31.

14. Manetti ML, Marziale MHP. Fatores associados à depressão relacionada ao trabalho de enfermagem. Estud Psicol (Natal) [Internet]. 2007 [citado em 2014 out 12];12(1):79-85. Disponível em: http://www.scielo.br/pdf/epsic/v12n1/a10v12n1.pdf

15. Paschoalini B, Oliveira MM, Frigério MC, Dias ALRP, Santos FH. Efeitos cognitivos e emocionais do estresse ocupacional em profissionais de enfermagem. Acta Paul Enferm [Internet]. 2008 [citado 2014 out. 12];21(3):487-92. Disponível em: http://www.scielo.br/pdf/ape/ v21n3/pt_17.pdf

16. Boya FO, Demiral Y, Ergor A, Akvardar Y, De Witte H. Effects of perceived job insecurity on perceived anxiety and depression in nurses. Ind Health. 2008;46(6):613-9.

17. Tomás-Sábado J, Maynegre-Santaulària M, Pérez-Bartolomé M. Síndrome de burnout y riesgo suicida en enfermeras de atención primaria. EnfermClín. 2010;20(3):173-178.

18. Chiang YM, Chang Y. Stress, depression, and intention to leave among nurses in different medical units: Implications for healthcare management/nursing practice. Health Policy. 2012;108(2-3):149-57.

19. Czaja AS, Moss M, Mealer M. Symptoms of posttraumatic stress disorder among pediatric acute care nurses. J PediatrNurs. $2012 ; 27(4): 357-65$.

20. Lee JS, Joo EJ, Choi KS. Perceived stress and self-esteem mediate the effects of work-related stress on depression. Stress Health. $2013 ; 29(1): 75-81$.

21. Gomes RK, Oliveira VB. Depressão, ansiedade e suporte social em profissionais de enfermagem. Bol Psicol. $2013 ; 63(138): 23-33$.

22. Monteiro JK, Oliveira ALL, Ribeiro CS, Grisa GH, Agostini N. Adoecimento psíquico de trabalhadores de Unidade de Terapia Intensiva. PsicolCiêncProf [Internet]. 2013 [citado 2014 out. 15];33(2). Disponível em: http://www.scielo.br/pdf/pcp/v33n2/v33n2a09.pdf

23. Wang SM, Lai CY, Chang YY, Huang CY, Zauszniewski JA, Yu CY. The relationships among work stress, resourcefulness, and depression level in psychiatric nurses. Arch PsychiatrNurs. 2015;29(1):64-70.

24. Alderson M, Parent-Rocheleau X, Mishara B. Critical review on suicide among nurses. Crisis. 2015 Feb 23. [Epub ahead of print]

25. Cano-Langreo M, Cicirello-Salas S, López-López A, Aguilar-Vela M. Marco actual del suicidio e ideas suicidas en personal sanitario. Med Segur Trab. 2015;60(234):198-218.

26. Perry L, Lamont S, Brunero S, Gallagher R, Duffield C. The mental health of nurses in acute teaching hospital settings: a cross-sectional survey. BMC Nurs [Internet].2015 [cited 2015 Apr 13];14:15. Available from: http://www.ncbi.nlm.nih.gov/pmc/articles/PMC4405850/

27. Oliveira FP, Mazzaia MC, Marcolan JF. Symptoms of depression and intervening factors among nurses of emergency hospital services. Acta Paul Enferm [Internet].2015 [cited 2015 July 12];28(3):209-15. Available from: http://www.scielo.br/pdf/ape/v28n3/en_1982-0194ape-28-03-0209.pdf

28. Ávila LI, Silveira RS, Lunardi VL, Machado GFF, Mancia JR, Silveira JT. Implicações da visibilidade da enfermagem no exercício profissional. Rev Gaúcha Enferm [Internet]. 2013 [citado 2014 out. 25];34(3):102-19. Disponível em: http://seer.ufrgs.br/RevistaGauchadeEnfermagem/ article/view/37874

29. Oliveira JDS, Alchiere JC, Pessoa Júnior JM, Miranda FAN, Almeida MG. Nurses' social representations of work-related stress in an emergency room.Rev Esc Enferm USP [Internet]. 2013 [cited 2015 Jan 30];47 (4):984-9. Available from: http://www.scielo.br/pdf/reeusp/ v47n4/en_0080-6234-reeusp-47-4-0984.pdf

30. Cavalcante FG, Minayo MCS. Autópsias psicológicas e psicossociais de idosos que morreram por suicídio no Brasil. Ciênc Saúde Coletiva. $2012 ; 17(8): 1943-54$

31. Urbanetto JS, Magalhães MC, Maciel VO, Sant'Anna VM, Gustavo AS, Poli-de-Figueiredo CE, et al. Work-related stress according to the demand-control model and minor psychic disorders in nursing workers. Rev Esc Enferm USP [Internet]. 2013 [cited 2015 Feb 02];47(5):1186-93. Available from: http://www.scielo.br/pdf/reeusp/v47n5/0080-6234-reeusp-47-05-1180.pd

32. Maynart WHC, Albuquerque MCDS, Brêda MZ, Jorge JS. Qualified listening and embracement in psychosocial care. Acta Paul Enferm [Internet]. 2014 [cited 2015 Feb 01];27(4):300-3. Available from: http://www.scielo.br/pdf/ape/v27n4/en_1982-0194-ape-027-004-0300.pdf

33. Umann J, Guido LA, Silva RM. Stress, coping and presenteeism in nurses assisting critical and potentially critical patients. RevEsc Enferm USP [Internet]. 2014 [cited 2015 Feb 02];48(5):891-8. Available from: http://www.scielo.br/pdf/reeusp/v48n5/pt_00806234-reeusp-48-05-891.pdf

34. Guido LA, Linch GFC, Pitthan LO, Umann J. Stress, coping and health conditions of hospital nurses. Rev Esc Enferm USP [Internet]. 2011 [cited 2013 Dec 05];45(6):1434-9. Available from: http://www.scielo.br/pdf/reeusp/v45n6/en_v45n6a22.pdf

35. Overholser JC, Braden A, Dieter L. Understanding suicide risk: identification of high risk groups during high risk times. J Clin Psychol. 2012;68(3):349-361.

36. DeJong TM, Overholser JC, Stockmeier CA. Apples to oranges? A direct comparison between suicide attempters and suicide completers. J Affect Disord. 2010;124(1-2):90-7.

37. Bertolote JM, Mello-Santos C, Botega NJ. Detecção do risco de suicídio nos serviços de emergência psiquiátrica. RevBras Psiquiatr. 2010;32 Supl. 2:S87-S95.

38. Schwartz-Lifshitz M, Zalsman G, Giner L, Oquendo MA. Can we really prevent suicide? CurrPsychiatry Rep. 2012;14(6):624-33. 